\title{
Response of green snap bean plants to different plant densities and some chemical compounds under cool atmosphere condition
}

\author{
Doaa, M. Mostafa*, Abeer, I. Shabana and M.M.Ramadan \\ Agricultural Research Center, Hort. Res. Inst., Veg. Dep., Dokki, Giza, Egypt. \\ *corresponding author: E-mail: d_flower88@yahoo.com
}

\begin{abstract}
The present study was carried out during the two successive fall seasons of 2017 and 2018, at private farm in Kafr El-Sheik Governorate, under clay soil condition using furrow irrigation system. These experiments aimed to evaluate the effect of some combinations among four plant densities $\left(20,30,40\right.$ and 60 plants $\left./ \mathrm{m}^{2}\right)$ with four types of chemical compounds (its symbols i.e., chemical compound 1, 2, 3 and 4) beside the control treatment on growth, yield and pods quality of snap bean (Phaseolus vulgaris L.) cv.Polista as a famous variety, grown under open field conditions. This study aimed to introduce a practical solution to resist atmospheric changes and instability in temperature and especially sudden sharp recursively during growth and fall season.

All studied densities gave rise to a positive effect on plant growth expressed as plant height, number of branches per plant, number of leaves per plant, leaf area per plant, foliage fresh weight and foliage dry weight per plant compared with control treatments.

Positive impact in comparison with the treatments of the promo, which recorded the highest values of vegetation such as plant height, number of branches per plant and number of leaves / plant when growing 40 plants $/ \mathrm{m}^{2}$ and using chemical compound 2, while cultivating 30 plants $/ \mathrm{m}^{2}$ with chemical compound 1 gave the highest values of fresh and dry weight, Leaf area and the stem diameter. Regarding the influence of interference on the pod weight in the first season only, the length of the pod and the number of pods/plant in both seasons did not show any differences moral consequences, while cultivating 30 plants $/ \mathrm{m}^{2}$ with chemical compound 2 gave higher values for the pod weight in the second season, the length of the pod and the total yield, if using 30 plants $/ \mathrm{m}^{2}$ with chemical compound 1 record higher values for the pod thickness. Regarding the chemical content of the leaves as chlorophyll, nitrogen, potassium, recorded the highest values when growing 30 plants $/ \mathrm{m}^{2}$ with chemical compound 2, except the highest phosphorus values when planting 30 plants $/ \mathrm{m}^{2}$ with chemical compound 1 . Also treatment 30 plants $/ \mathrm{m}^{2}$ with chemical compound 1 gave higher values for the content of vitamin C, TSS and less fiber content and acidity and therefore get the high yield plus high quality.
\end{abstract}

KEYWORS: plant densities, cytokinin, indol butyric acid, sea algae extract, macro and micro elements, snap bean pods yield, green snap bean quality.

\section{INTRODUCTION}

Snap bean (Phaseolus vulgaris L.) considered as one of the most important vegetable crops grown in Egypt for both local consumption and exportation. It plays an important role in human nutrition as a cheap source for protein, carbohydrates, vitamins and minerals.

Plant density considered as one of main factors affecting bean yield. The number of plants per unit area was controlled by variation in plant spacing between and within rows. Tompkins et al., (1974) found that plant height of french bean cultivars decreased with increasing spacing between plants from $5-15 \mathrm{~cm}$. and low density planting. Leaf area and leaf area index of phaseolus vulgaris at flowering stage were higher at $15 \mathrm{~cm}$. spacing between plants than 5 or $7.5 \mathrm{~cm}$. and varied inversely with plant population and cultivars ( Appadural et al.,1974 ).

Waters et al., (1983) showed that increasing plant population of some snap bean cultivars reduced the fresh weight of all other plant parts and induced severe effect on branch number. A ppadural et al.,(1974) found that $15 \mathrm{~cm}$. spacing between snap bean plants obtained significantly higher green yield, while, Tompkins et al.,( 1974). Argerich and Calvar (1986) resulted higher green pod yield of snap bean at the low spacing and high density planting with much higher percentage of small pods, pale color and non-homogeneity of shape that caused reduction in pod number and weight per plant.

Many researchers found that increasing plant density of snap bean increased total grain yield of all studied cultivars, but had bad effect on number of Pods/plant, seed yield/plant, number of seeds/pod and the weight of 100 seeds (Edje et al., 1973; Barreto, 1983; Lollato et al., 1983 and Waters et al., 1983).

Moreover, Silva (1984) obtained highest seed yield of beans at $80 \mathrm{~cm}$. row width and 350000 plants/ha in double rows and followed by $60 \mathrm{~cm}$. row width and 250000 plants /ha in single row, Ali and Tripathi (1988) found that the numbers of pods /plant, 100 seed weight and seed yield increased with increasing plant density of 3 french bean cultivars while Dwivedia et al., (1994) obtained highest seed yield of French bean at the spacing of 8 $\mathrm{cm}$. between plants and density of 400000 plants/ ha. Plant density had little effect on carbohydrate and nitrogen content of seeds (Waters et al., 1983). 


\section{Scientific Journal of Agricultural Sciences 1 (1): 1-13, 2019}

Many investigations recorded that bean plants are very sensitive to climate change, especially weather fluctuations within one planting season (Dale, 1964, singer et a., 1996 and El-Tohamy et al., 1999).

However, bean plants are relatively sensitive to environmental stresses where occur under field conditions, compared to most vegetable crops which negatively affected its growth, yield and even quality. Under such stressful environmental conditions and the consequences of exposure to low temperature relatively, reduction in yield and different performances could be expected (Buis et al., 1988, Fryer et al., 1995, Greaves, 1996 and Haldiman, 1998). The degree of plant tolerance to environmental stress varies greatly not only between species but also in different varieties of the same species (Wentworth et al., 2006).

One of the ways for improving tolerance of bean plants to the possible environmental stresses by using different agricultural treatments to enhance growth and maximize the yield. The presence of mineral elements such as potassium, phosphorus, nitrogen, sulfur, zinc, boron and molybdenum also antioxidant or plant growth regulators act as factors for some enzymes, i.e., dismutases, catalase and peroxidases those catalyzed break down of the toxic $\mathrm{H}_{2} \mathrm{O}_{2}, \mathrm{OH}, \mathrm{O}_{2}$ radicals (Romheld and Marschner ,1991 and Bowler et al.,19992). Also explained that $\mathrm{K}$ in plants is involved in photosynthesis, assimilate transport, enzyme activation, and oxidative stress. Deficiency of this element in the initial growth stage significantly disturbs the distribution of assimilates between above-ground organs and roots. Deficiency of the element in soil may lead to fewer primordial and impede the nitrogen (N2) fixation mechanism, which may be linked to lower protein content in seeds.

Sulfur also plays a vital role in N2 fixation. To improve the $\mathrm{S}$ supply in faba bean, potassium sulphate $\left(\mathrm{K}_{2} \mathrm{SO}_{4}\right)$ fertilizers are mostly used. In this way, two nutrients are applied simultaneously.

Compounds contain of amino acids and cytokinins have stimulatory effects on bean plants. It has a beneficial role during vegetative and reproductive growth through improving flower formation and their set in some plants, also plays a vital role of enhancement carbohydrates accumulation exactly during stress (Barnett et al., 1990), as well as ,enhancing the accumulation of chlorophyll and delay senescence( Mattagagajasingh and Kar, 1989 and Novabour et al.,2003) . Auxin as IBA (Indole -butyric Acid) plays a supporter role with cytokinins on plant growth (Wilkins, 1984).

Extracts derived from algae contain such components as polysaccharides (e.g., galactan, fucoidan, alginate, and laminarin), proteins (e.g., lectins), polyunsaturated fatty acids (PUFAs), pigments (e.g., chlorophylls, carotenoids, and phycobiliproteins), polyphenols (e.g., phenolic acids, flavonoids, cinnamic acid, isoflavones, benzoic acid, and lignans, quercetin), minerals (e.g., $\mathrm{K}, \mathrm{Mg}, \mathrm{Ca}$, and $\mathrm{Na}$ ), and plant growth hormones (e.g., cytokinins, auxins, gibberellins, and abscisic acid) . Scientific research has proven that some algal metabolites show potential antioxidant, antiproliferative, ant diabetic, antitumor, antiinflammatory, antiallergic, and anti-HIV properties ( Chojnacka et al., 2012).

Thereby, the present study aimed to use some commercial compounds which can enhance growth, with different plant density, in autumn season, when plants are exposed to unstable waves of low cold temperatures or climate changes, especially weather fluctuations within one planting season.

\section{MATERIALS AND METHODS}

The present study was carried out during the two successive fall seasons of 2017 and 2018, at private farm in Kafr El-Sheik Governorate, under clay soil condition using furrow irrigation system. These experiments aimed to evaluate the effect of some combinations between plant density with types of chemical compounds additions plus the control treatment (without any chemical additions) on growth, yield and pod quality of snap bean (Phaseolus vulgaris L.) cv.Polista

\subsection{The experimental design and treatments:}

The experimental layout was split plot system in a randomized complete blocks design with three replicates. The experiment includes 20 treatments which were the combination among four densities, four chemical compounds applications, beside the control treatment (without chemical compounds applications).The densities were randomly arranged in the main plots, while the chemical compounds treatments were randomly distributed in the sub plots. The treatments were arranged as follow:

\subsubsection{Densities:}

a. 20 plants $/ \mathrm{m}^{2}$ (seeds sowing at $10 \mathrm{~cm}$ at one side/ridges).

b. 30 plants $/ \mathrm{m}^{2}$ (seeds sowing at $7 \mathrm{~cm}$ at one side/ridges).

c. 40 plants $/ \mathrm{m}^{2}$ (seeds sowing at $10 \mathrm{~cm}$ at two sides/ridges under the method of agriculture man crow).

d. 60 plants $/ \mathrm{m}^{2}$ (seeds sowing at $7 \mathrm{~cm}$ at two sides/ridges under the method of agriculture man crow). 
Doaa, M. Mostafa et al., 2019

\subsubsection{Chemical compounds applications:}

a. Chemical compound 1; at 4litre/fed. (Obtained from commercial company) consists of (50\% potassium acitate-200.0\% cytokinin-BA6).

b. Chemical compound 2; at 2litre/fed. (Obtained from commercial company) consists of (P-Bo$\mathrm{Zn}-\mathrm{N}-\mathrm{Mo}-\mathrm{Fe}-\mathrm{K}-\mathrm{IBA}$-Amino acids-Volvic acid - sea algae extract).

c. Chemical compound 3; acts traditional agriculture treatment using calcium super phosphate and potassium sulphate extract $(1 \mathrm{~K}$ : $2 \mathrm{P} \%)$.

d. Chemical compound 4; acts traditional agriculture treatment also using mixture of liquid potassium oxide $(37 \%) 250 \mathrm{~cm} / \mathrm{L}+(40 \%)$ phosphoric acid70cm $/ 100 \mathrm{~L}+150 \mathrm{~cm}$ liquid sulfur $200 \mathrm{~cm} / 100 \mathrm{~L}$

e. Control (without any of last compounds).

The plants were treated with the four chemical compounds three times, 20 days after sowing and repeated each15-20 days interval. The normal agricultural practices of snap bean production were followed according to the recommendations of Egyptian Ministry of Agriculture. The physical and chemical properties of the experimental soil are presented in Table (1).

Table 1. Physical and chemical characteristics of soil sampled collected from the experiment location in the two seasons of 2017 and 2018.

\begin{tabular}{|c|c|c|}
\hline Properties & Season 2017 & Season 2018 \\
\hline \multicolumn{3}{|c|}{ Physical properties } \\
\hline Clay \% & 45.2 & 39.5 \\
\hline Silt $\%$ & 35.1 & 37.2 \\
\hline Sand \% & 21.8 & 23.4 \\
\hline Soil texture & Clay loam & Clay loam \\
\hline \multicolumn{3}{|c|}{ Chemical properties } \\
\hline$* \mathbf{P H}$ & 8.5 & 8.3 \\
\hline$* * \mathbf{E C}(\mathbf{d S m}-1)$ & 3.35 & 3.32 \\
\hline O.M. & 0.82 & 0.85 \\
\hline \multicolumn{3}{|c|}{ Soluble cations (meqll): } \\
\hline $\mathrm{Ca}++$ & 3.8 & 4.6 \\
\hline $\mathbf{M g}+$ & 3.6 & 2.9 \\
\hline $\mathbf{K}+$ & 21 & 19 \\
\hline $\mathrm{Na}$ & 7.2 & 7.4 \\
\hline \multicolumn{3}{|c|}{ Soluble anions: } \\
\hline CO3-- & 3.1 & 3.3 \\
\hline HCO3- & 1.7 & 1.9 \\
\hline CL- & 5.5 & 5.6 \\
\hline SO4-- & 2.9 & 3.2 \\
\hline Total N\% & 0.19 & 0.18 \\
\hline Available phosphorus & 30.9 & 30.7 \\
\hline
\end{tabular}

* measured in 1:25 soil water suspension; ** measured in the water extract of saturation soil paste.

\subsection{Data recorded:}

\subsubsection{Vegetative growth:}

At 60 days after sowing, random samples of five plants from each plot were taken for determination of:

a. Plant fresh weight (g).

b. Plant dry weight $(\mathrm{g})$.

c. Plant height $(\mathrm{cm})$

d. Number of main branches per plant.

e. Leaf area per plant in $\mathrm{cm} 2$ was measured after the first fruit harvest according to Yousri (1990

f. Number of leaves per plant.

g. Stem diameter (mm).

\subsubsection{Pod yield and its components:}

Green pods were picked at the proper maturing stage through the harvesting period for estimation of yield parameters, i.e., pod length $(\mathrm{cm})$, pod diameter $(\mathrm{mm})$, average pod weight (gm.), number of pods/ plant and total yield ( ton per feddan).

\subsubsection{Chemical composition of leaves:}

Mineral elements were determined in all leaves after 15 days from last addition of fertilizer doses, however; samples were dried at $70{ }^{\circ} \mathrm{C}$ to determine total nitrogen, phosphorus and potassium content according to the methods described by Black (1983),Watanabe and Olsen (1965) and Jackson (1965), respectively. Whereas, total chlorophyll was 
determined using spectrophotometer according to the methods described by Lichtenthaler and Wellburn (1983).

\subsubsection{Chemical properties of pods:}

Chemical properties of pods i.e., TSS,ascorbic acid (vitamin C), titrable acidity(\%) and crude fibers were recorded according to the method by A.O.A.C.(1980) and crude fibers according to Maynard (1970).

\subsubsection{Statistical analysis:}

The obtained data were subjected to the combined analysis of variance procedure and means compared using L.S.D. methods at 5\% level of significance according to Snedecor and Cochran (1980).

\section{RESULTS AND DISCUSSION}

\subsection{Vegetative growth character:}

\subsubsection{Effect of plant densities:}

Data in Table (2) reveal that the plant height, number of branches / plant, number of leaves/plant, leaf area/ plant as well as fresh and dry weight of snap bean plants were significantly responded with the increment of the plant density from 20 plants/ $\mathrm{m} 2$ to 40 plants $/ \mathrm{m} 2$. Whereas, It could be summarized that, the growth characteristics of snap bean plants recorded superiority the highest value when planted at 40 plants $/ \mathrm{m} 2$ followed by 60 plants/ $\mathrm{m} 2$ without significant differences between them. In this regard, Amer et al., ( 2001 ) studied the effect of plant densities ( 11,22 and 33 plants $/ \mathrm{m} 2$ ) on pea plants, the results showed that increasing plant density to 33 plants $/ \mathrm{m} 2$ decreased the number leaves, Moreover, Yucel (2013) found that plant height and number of leaves were affected by plant densities when planting at 40 plants/ $\mathrm{m} 2$ was favorable in wintrily seasons. Darwesh (2012) on cowpea, Kazemi et al., (2012) and Khairy (2013) on snap bean reported that hight plant density obtained higher values of plant high and low values of number of leaves as well as plant fresh and dry weight ,although low density were occurred the opposite of these results.

\subsubsection{Effect of different sources of chemical compounds:}

The results presented in Table (2) showed that the vegetative growth of snap bean plants was significantly affected by addition of different sources of chemical compounds in the two experimental seasons. According to the values of leaf area, fresh and dry weight recorded that treated plants by compound 1 and 2 surpassed the other treatments in both seasons. However, compound 2 recorded the highest values of leaf area $(1198.60$ and $1201.40 \mathrm{~cm} 2)$, fresh weight (45.60 and $52.50 \mathrm{gm}$ ) and dry weight (8.61 and $10.38 \mathrm{gm}$ ) in both seasons, respectively. Moreover, the lowest values of leaf area (1017.56 and $1026.35 \mathrm{~cm} \mathrm{2),} \mathrm{fresh} \mathrm{weight}$ (34.47 and $37.91 \mathrm{gm}$. ) and dry weight (6.18 and 6.34 gm) were noticed with untreated plants.

The results revealed that the compound 1 and compound 2 treatments recorded the highest values of plant highest $(37.11$ and $36.00 \mathrm{~cm}$.$) and (38.88$ and $38.38 \mathrm{~cm}$.), stem diameter $(6.25$ and $6.03 \mathrm{~mm})$ and (6.36and $5.03 \mathrm{~mm}$ ), number of branches (4.77 and 4.55) and (5.76 and 5.88) and number of leaves (16.67 and 16.86) and ( 21.11and 20.85) in both seasons, respectively compared with compound 3 and 4 treatments. The control plants recorded the

Table 2. Effect of plant densities and different sources of chemical compounds on vegetative growth of snap bean during 2017 and 2018.

\begin{tabular}{|c|c|c|c|c|c|c|c|c|c|c|c|c|c|c|c|}
\hline \multirow{2}{*}{\multicolumn{2}{|c|}{$\begin{array}{l}\text { Characters } \\
\text { Treatments }\end{array}$}} & \multicolumn{2}{|c|}{$\begin{array}{c}\text { Foliage } \\
\text { fresh } \\
\text { weight/plant } \\
\text { (gm.) }\end{array}$} & \multicolumn{2}{|c|}{$\begin{array}{c}\text { Foliage dry } \\
\text { weight/ } \\
\text { plant (gm.) }\end{array}$} & \multicolumn{2}{|c|}{$\begin{array}{c}\text { Plant } \\
\text { height }(\mathbf{c m})\end{array}$} & \multicolumn{2}{|c|}{$\begin{array}{c}\text { No. of } \\
\text { branches/plant }\end{array}$} & \multicolumn{2}{|c|}{$\begin{array}{c}\text { Leaf area/ plant } \\
\left(\mathrm{cm}^{2}\right)\end{array}$} & \multicolumn{2}{|c|}{$\begin{array}{c}\text { No. of I } \\
\text { eaves/ plant }\end{array}$} & \multicolumn{2}{|c|}{$\begin{array}{l}\text { Stem } \\
\text { diameter } \\
\quad(\mathbf{m m})\end{array}$} \\
\hline & & 2017 & 2018 & 2017 & 2018 & 2017 & 2018 & 2017 & 2018 & 2017 & 2018 & 2017 & 2018 & 2017 & 2018 \\
\hline \multirow{4}{*}{$\underset{\text { densities }}{\text { Plant }}$} & 20 plants $/ \mathrm{m}^{2}$ & 38.56 & 43.18 & 6.99 & 8.16 & 33.94 & 35.82 & 4.05 & 4.10 & 1065.15 & 1098.87 & 15.65 & 16.66 & 4.96 & 5.58 \\
\hline & 30 plants $/ \mathrm{m}^{2}$ & 39.18 & 45.68 & 7.64 & 8.27 & 35.98 & 37.31 & 4.65 & 4.93 & 1078.23 & 1100.28 & 16.86 & 17.67 & 5.04 & 5.98 \\
\hline & 40 plants $/ \mathrm{m}^{2}$ & 43.04 & 47.11 & 6.71 & 8.93 & 37.93 & 40.53 & 6.40 & 6.60 & 1095.74 & 1124.89 & 19.78 & 20.51 & 6.52 & 6.58 \\
\hline & 60 plants $/ \mathrm{m}^{2}$ & 44.18 & 48.68 & 8.64 & 9.97 & 38.96 & 39.49 & 3.55 & 3.73 & 1059.04 & 1029.228 & 13.98 & 13.56 & 6.44 & 6.38 \\
\hline \multirow[t]{2}{*}{ L.S.D. at $5 \%$} & & 1.552 & 1.623 & 0.44 & 0.258 & 1.272 & 1.684 & 1.21 & 1.33 & 8.274 & 23.210 & 2.532 & 2.459 & 0.301 & 0.420 \\
\hline & Compound 1 & 39.68 & 48.74 & 7.48 & 9.45 & 36.00 & 37.11 & 4.55 & 4.77 & 1085.31 & 1119.73 & 16.86 & 16.67 & 6.03 & 6.55 \\
\hline \multirow{4}{*}{$\begin{array}{l}\text { Sources of } \\
\text { chemical } \\
\text { compounds }\end{array}$} & Compound 2 & 45.60 & $\mathbf{5 2 . 5 0}$ & 8.61 & 10.38 & 38.38 & 38.88 & 5.88 & 5.76 & 1198.60 & 1201.40 & 20.85 & 21.11 & 5.03 & 6.36 \\
\hline & Compound 3 & 37.53 & 43.06 & 6.61 & 7.46 & 34.33 & 35.33 & 3.44 & 3.66 & 1062.24 & 1068.95 & 14.68 & 15.53 & 5.74 & 6.00 \\
\hline & Compound 4 & 37.33 & 44.40 & 6.67 & 8.01 & 34.22 & 35.33 & 3.30 & 3.64 & 1073.70 & 1101.84 & 13.90 & 14.42 & 5.53 & 5.87 \\
\hline & Control & 34.47 & 37.91 & 6.18 & 6.34 & 31.77 & 32.55 & 2.02 & 2.11 & 1017.56 & 1026.35 & 9.22 & 9.38 & 4.91 & 5.13 \\
\hline \multicolumn{2}{|l|}{ L.S.D. at 5\% } & 0.634 & 1.081 & 0.166 & 0.210 & 1.648 & 1.575 & 1.378 & 1.410 & 10.209 & 17.762 & 2.507 & 2.425 & 0.226 & 0.322 \\
\hline
\end{tabular}


lowest values of plant height (32.55and 31.77 $\mathrm{cm}$.), stem diameter (5.13 and $4.91 \mathrm{~mm})$, number of branches (2.11 and 2.02) and number of leaves (9.38 and 9.22), respectively in the two growing seasons.

The favorability effect of compound 1 and compound 2 compared to other treatments and control may be due that the two compounds contain of cytokinins, types of auxins, free amino acids , micro elements and sea algae extracts also antioxidants which protect the plants against the diverse condition.

As for chemical compound 1 which consists of cytokinins, its favorable effect on vegetative growth of snap bean might be due to its role as a plant growth stimulator ( Mahmood et al., 2010 and Basra et al., 2011 ). Moreover, potassium acetate and (butyric acid -6) accelerate the growth of plants, strengthen plants and improve resistance against pests and diseases (Hussain et al., 2013). In this context, Emongor (2015) reported that cytokinins have a role in reducing the plastochron and /or increasing cell division of snap bean plants.

The beneficial effects of compound 2 due to its contains of auxins, amino acids , micro elements and sea algae extracts also antioxidant which play an essential role in the regulation of plant growth ,development and interaction with other organisms and it was called a plant hormone (Harborne,1980 and Raskin,1992 ). Indeed, it has beneficial effect for catching the abundant reactive oxygen species (ROS) that cause senescence and loss of plasma membrane permeability and death of cells within plant tissues (Bodannes and Chan, 1979), a signal transduction or messenger (Klessing and Malamy, 1994) and a growth regulator which participates in the regulation of physiological processes in plants ( Umebese et al., 2009).

\subsubsection{Effect of the interaction between densities and different sources of chemical compounds:}

Data in Table (3) illustrated that snap bean plants growth were affected as a result of the different combinations between densities and different sources of chemical compounds .It is obviously that the combinations were significantly differed compared with the control treatment in the two seasons of this study, On the other hand, the four studied plant densities equally responded to the different sources of chemical compounds treatments. As for, density at 40 plants $/ \mathrm{m} 2$ with chemical compound 2 recorded the highest means of plant height (43.56and $42.33 \mathrm{~cm}$.), number of branches (7.50 and 7.66) and number of leaves (15.33and $15.96)$, in both seasons, respectively, whereas the highest values of stem diameter $(6.83$ and $7.00 \mathrm{~mm})$ were noticed at density 30 plants $/ \mathrm{m} 2$ with chemical compound 1 , respectively, in both seasons.
Regarding to the leaf area, fresh and dry weight, the results in the previous table declared that the interaction between densities and different sources of chemical compounds were significant, whereas the highest values of them were achieved at 30 plants/m 2 with chemical compound 2 .

\subsection{Green pods yield and its characteristic:}

\subsubsection{Effect of plant densities:}

Results in Table (4) showed the effect of plant densities on some characters of snap bean i.e., pod length, pod diameter, pod weight, number of pods/plant and total green pod yield/ feddan. Data showed that, there is no significant effect from using all plant densities on pod length in both seasons The results explained that plant density at 40 plants $/ \mathrm{m} 2$ had the highest values to pod diameter and pod weight in the two seasons, whereas, plant density 60 plants $/ \mathrm{m} 2$ in the two seasons showed higher values than other treatments according to number of pods/plant and total green pod yield /fed. The results cleared that, the production from plants grown under the density of 60 plants/ $\mathrm{m} 2$ had the highest values in both growing seasons followed by the plants at density 40plants $/ \mathrm{m} 2$ with significant differences between them in both seasons. Data revealed that increasing snap bean plants densities decreased yield components, while the total yield was increased by increasing plant density. These results were in agreement with Moot and Mcneil (1995), ElAtabany (2000), Amer et al., (2001), Rasaei et al., (2012) and Yucel (2013) on pea plants.

\subsubsection{Effect of different sources of chemical compounds:}

It is obvious from data in Table (4) that all different sources of chemical compounds significantly increased all studied parameters, i.e., pod length, pod diameter, pod weight, pods number/ plants and total pod yield /feddan compared with the control in both seasons.

Treating snap bean plants with chemical compound 2 gave the best results as for pod length (12.00 and $12.22 \mathrm{~cm}$.), pod weight (5.81 and 6.21 gm), number of pods/plant (14.77 and 16.66) and total pod yield (4.699and 4.868 ton/fed.) in both seasons, respectively followed by chemical compound 1, while, control plants recorded the lowest values in the two seasons.

Add that, chemical compound 1 treatment gave the highest values of pod diameter (7.87 and 7.92 $\mathrm{mm}$ ) and the control plants recorded the lowest values with $(6.10$ and $6.52 \mathrm{~mm})$ in both seasons, respectively.

The stimulatory influence of treating by chemical compound 2 on yield may be due to its bio 
Scientific Journal of Agricultural Sciences 1 (1): 1-13, 2019

Table 3. Effect of the interaction between plant densities and different sources of chemical compounds on vegetative growth of snap bean during 2017 and 2018.

\begin{tabular}{|c|c|c|c|c|c|c|c|c|c|c|c|c|c|c|c|}
\hline \multicolumn{2}{|c|}{$\begin{array}{l}\text { Characters } \\
\text { Treatments }\end{array}$} & \multicolumn{2}{|c|}{$\begin{array}{c}\text { Foliage fresh } \\
\text { weight/plant } \\
\text { (gm.) }\end{array}$} & \multicolumn{2}{|c|}{$\begin{array}{c}\text { Foliage dry } \\
\text { weight/ plant } \\
\text { (gm.) }\end{array}$} & \multicolumn{2}{|c|}{$\begin{array}{l}\text { Plant height } \\
(\mathrm{cm})\end{array}$} & \multicolumn{2}{|c|}{$\begin{array}{c}\text { No. of } \\
\text { branches/plant }\end{array}$} & \multicolumn{2}{|c|}{$\begin{array}{c}\text { Leaf area/ plant } \\
\left(\mathrm{cm}^{2}\right)\end{array}$} & \multicolumn{2}{|c|}{$\begin{array}{c}\text { No. of } 1 \\
\text { eaves/ plant }\end{array}$} & \multicolumn{2}{|c|}{$\begin{array}{c}\text { Stem } \\
\text { diameter } \\
(\mathbf{m m})\end{array}$} \\
\hline $\begin{array}{c}\text { Plant } \\
\text { density }\end{array}$ & $\begin{array}{c}\text { Sources of } \\
\text { chemical } \\
\text { compounds }\end{array}$ & 2017 & 2018 & 2017 & 2018 & 2017 & 2018 & 2017 & 2018 & 2017 & 2018 & 2017 & 2018 & 2017 & 2018 \\
\hline \multirow{5}{*}{$\stackrel{20}{\text { plants } / \mathrm{m}^{2}}$} & Compound 1 & 39.23 & 48.90 & 7.43 & 9.43 & 36.33 & 37.00 & 5.66 & 5.66 & 1073.73 & 1127.93 & 11.66 & 12.66 & 5.43 & 6.30 \\
\hline & Compound 2 & 44.26 & 52.26 & 8.46 & 10.16 & 38.33 & 39.00 & 6.66 & 6.00 & 1104.50 & 1133.23 & 12.66 & 13.66 & 5.53 & 6.06 \\
\hline & Compound 3 & 37.26 & 43.06 & 6.63 & 7.46 & 34.66 & 36.33 & 3.53 & 3.66 & 1062.03 & 1099.90 & 11.00 & 11.33 & 5.43 & 5.70 \\
\hline & Compound 4 & 37.26 & 43.43 & 6.26 & 7.26 & 34.00 & 34.66 & 3.53 & 3.62 & 1064.33 & 1102.33 & 10.66 & 11.00 & 5.20 & 5.33 \\
\hline & Control & 34.73 & 38.23 & 6.16 & 6.46 & 31.33 & 32.00 & 3.10 & 300 & 1023.93 & 1035.00 & 9.00 & 9.00 & 4.70 & 5.03 \\
\hline \multirow{6}{*}{$\begin{array}{c}30 \\
\text { plants } / \mathrm{m}^{2}\end{array}$} & Compound 1 & 41.20 & 49.93 & 7.96 & 10.36 & 36.00 & 38.33 & 5.66 & 5.00 & 1119.40 & 1144.50 & 12.66 & 13.33 & 6.83 & 7.00 \\
\hline & Compound 2 & 51.13 & 55.13 & 9.26 & 11.16 & 39.16 & 40.33 & 6.70 & 6.55 & 1159.20 & 1186.46 & 13.66 & 15.66 & 6.13 & 6.76 \\
\hline & Compound 3 & 38.90 & 46.00 & 7.10 & 8.43 & 35.66 & 36.33 & 4.33 & 3.66 & 1078.63 & 1058.60 & 11.33 & 11.66 & 6.06 & 6.23 \\
\hline & Compound 4 & 38.10 & 47.70 & 7.40 & 9.56 & 35.33 & 37.66 & 3.66 & 3.66 & 1098.06 & 1115.46 & 11.66 & 12.00 & 5.86 & 6.46 \\
\hline & Control & 36.56 & 39.63 & 6.46 & 6.83 & 33.66 & 34.33 & 3.08 & 3.33 & 1038.50 & 1041.40 & 10.00 & 10.16 & 5.30 & 5.46 \\
\hline & Compound 1 & 38.63 & 47.40 & 7.06 & 8.56 & 40.63 & 41.00 & 5.33 & 5.66 & 1062.80 & 1086.76 & 15.33 & 15.69 & 5.83 & 6.36 \\
\hline \multirow{4}{*}{$\begin{array}{c}40 \\
\text { plants } / \mathrm{m}^{2}\end{array}$} & Compound 2 & 41.40 & 50.11 & 8.10 & 9.56 & 43.56 & 42.33 & 7.50 & 7.66 & 1092.10 & 1128.50 & 18.43 & 18.05 & 5.76 & 6.26 \\
\hline & Compound 3 & 36.43 & 40.13 & 6.10 & 6.50 & 32.66 & 33.33 & 4.33 & 4.65 & 1046.06 & 1048.36 & 14.33 & 14.66 & 5.73 & 6.06 \\
\hline & Compound 4 & 36.63 & 42.06 & 6.36 & 7.20 & 33.33 & 33.66 & 4.33 & 4.56 & 1058.70 & 1087.73 & 14.39 & 13.96 & 5.53 & 5.83 \\
\hline & Control & 32.13 & 35.86 & 5.93 & 5.73 & 30.33 & 31.33 & 3.00 & 3.00 & 990.26 & 1002.66 & 12.00 & 12.00 & 4.73 & 4.90 \\
\hline \multirow{6}{*}{$\begin{array}{c}60 \\
\text { plants } / \mathrm{m}^{2}\end{array}$} & Compound 1 & 37.44 & 38.99 & 6.15 & 7.88 & 35.54 & 36.81 & 5.56 & 5.90 & 1034.80 & 1039.76 & 12.95 & 11.99 & 4.20 & 4.34 \\
\hline & Compound 2 & 39.50 & 39.53 & 7.52 & 8.51 & 38.41 & 37.99 & 6.31 & 6.35 & 1040.15 & 1045.51 & 14.87 & 14.50 & 4.33 & 4.51 \\
\hline & Compound 3 & 35.33 & 37.32 & 5.32 & 5.54 & 35.08 & 34.90 & 4.33 & 4.50 & 1022.09 & 1024.37 & 11.90 & 11.54 & 4.04 & 4.31 \\
\hline & Compound 4 & 34.70 & 37.98 & 5.33 & 6.21 & 35.55 & 35.05 & 3.52 & 3.46 & 1018.75 & 1017.93 & 11.87 & 11.98 & 4.11 & 4.32 \\
\hline & Control & 31.54 & 34.51 & 4.80 & 4.63 & 31.37 & 32.55 & 3.21 & 3.22 & 894.26 & 998.67 & 10.99 & 11.05 & 4.01 & 4.00 \\
\hline & L.S.D. at $5 \%$ & 1.098 & 1.86 & 0.288 & 0.364 & 1.123 & 0.996 & 1.1 & 1.3 & 17.683 & 30.764 & 2.42 & 1.99 & 0.311 & 0.410 \\
\hline
\end{tabular}

*N.S. not significant

Table 4. Effect of plant densities and different sources of chemical compounds on green pod yield and its characteristic of snap bean during 2017 and 2018.

\begin{tabular}{|c|c|c|c|c|c|c|c|c|c|c|c|}
\hline \multirow{2}{*}{$\begin{array}{c}\text { Characters } \\
\text { Treatments }\end{array}$} & & \multicolumn{2}{|c|}{$\begin{array}{l}\text { Pod length } \\
\quad(\mathrm{cm})\end{array}$} & \multicolumn{2}{|c|}{$\begin{array}{l}\text { Pod diameter } \\
(\mathbf{m m})\end{array}$} & \multicolumn{2}{|c|}{$\begin{array}{l}\text { Pod weight } \\
\quad \text { (gm.) }\end{array}$} & \multicolumn{2}{|c|}{$\begin{array}{l}\text { Number of } \\
\text { pods/ plant }\end{array}$} & \multicolumn{2}{|c|}{$\begin{array}{l}\text { Total green pods } \\
\text { yield/plant } \\
\text { (ton/fed.) }\end{array}$} \\
\hline & & 2017 & 2018 & 2017 & 2018 & 2017 & 2018 & 2017 & 2018 & 2017 & 2018 \\
\hline \multirow{4}{*}{ Plant densities } & 20 plants $/ \mathrm{m}^{2}$ & 11.13 & 11.53 & 6.30 & 6.74 & 4.43 & 4.88 & 13.53 & 15.33 & 4.385 & 4.556 \\
\hline & 30 plants $/ \mathrm{m}^{2}$ & 11.70 & 11.80 & 7.33 & 7.83 & 5.67 & 5.94 & 14.26 & 16.33 & 4.489 & 4.655 \\
\hline & 40 plants $/ \mathrm{m}^{2}$ & 11.73 & 11.86 & 7.95 & 7.66 & 6.92 & 6.64 & 12.80 & 14.53 & 4.324 & 4.486 \\
\hline & 60 plants $/ \mathrm{m}^{2}$ & 11.70 & 11.80 & 7.00 & 7.10 & 5.67 & 5.94 & 14.86 & 16.37 & 4.589 & 4.695 \\
\hline \multirow{7}{*}{$\begin{array}{l}\text { Sources of chemical } \\
\text { compounds }\end{array}$} & L.S.D. at 5\% & NS & NS & 0.099 & 0.075 & 0.214 & 0.217 & 0.261 & 0.692 & 0.018 & 0.020 \\
\hline & Compound 1 & 11.83 & 12.11 & 7.87 & 7.92 & 5.47 & 5.82 & 14.00 & 15.88 & 4.510 & 4.675 \\
\hline & Compound 2 & 12.00 & 12.22 & 7.35 & 7.39 & 5.81 & 6.21 & 14.77 & 16.66 & 4.699 & 4.868 \\
\hline & Compound 3 & 11.77 & 11.88 & 6.91 & 7.47 & 5.33 & 5.57 & 13.33 & 15.22 & 4.342 & 4.232 \\
\hline & Compound 4 & 11.22 & 11.55 & 7.00 & 7.45 & 5.20 & 5.55 & 13.44 & 15.33 & 4.366 & 4.387 \\
\hline & Control & 10.77 & 10.88 & 6.10 & 6.52 & 5.06 & 5.26 & 12.11 & 13.88 & 4.116 & 4.199 \\
\hline & L.S.D. at $5 \%$ & 0.461 & 0.416 & 0.231 & 0.198 & 0.167 & 0.155 & 0.464 & 0.441 & 0.037 & 0.035 \\
\hline
\end{tabular}

regulator effect on ion uptake, cell division, cell inhibition of ethylene production (Lesilie and differentiations, protein synthesis and photosynthetic Romani,1986).

activity ( Blokhina et al., 2003 and EL-Tayeb,

Concerning the effect of chemical compound 2 2005). Moreover, it increases flower longevity via on snap bean yield, it may be due to its role in the regulation of photosynthesis, enhancing cell division 
and expansion, root elongation and transmembrane, electron transport (Smirnoff, 2000). Moreover, it contains endogenous cytokinins (zeatin ,dihydrozeatin and isopentyladenine ) which affect assimilate mobilization and/or distribution and increase pod set and pod number per branch in leguminous crops. (Emongor, 2015 and Kothule et al., 2003).

\subsubsection{Effect of the interaction between densities and different sources of chemical compounds:}

Table (5) show the effect of the interaction between densities and different sources of chemical compounds on pod length , pod diameter ,pod weight, number of pods per plant and total pod yield/feddan of snap bean. It is clear from the previous table that all combinations between density and different sources of chemical compounds have significant differences when compared with the control on all pod yield parameters, except pod weight in the first season and pod length and number of pods/plant in both seasons.However, treating snap bean plants with chemical compound 2 under density 30 plants $/ \mathrm{m}^{2}$ or 40 plants $/ \mathrm{m}^{2}$ produced the highest values of pod length, pod weight, number of pods per plant and total pod yield per feddan, while, treating by chemical compound 1 under density 30 plants $/ \mathrm{m}^{2}$ gave the highest pod diameter value in both seasons. Moreover, the lowest values of pod length, pod diameter, pod weight and total pod yield/feddan were recorded with untreated plants (control).

\subsection{Chemical components of leaves:}

\subsubsection{Effect of plant densities:}

Data in Table (6) showed the effect of plant densities on leaves content of N, P and $\mathrm{K}$ percentages during 2017 and 2018 seasons. The data showed that all studied densities significantly

Table 5. Effect of the interaction between plant densities and different sources of chemical compounds on green pod yield and its characteristic of snap bean during 2017 and 2018.

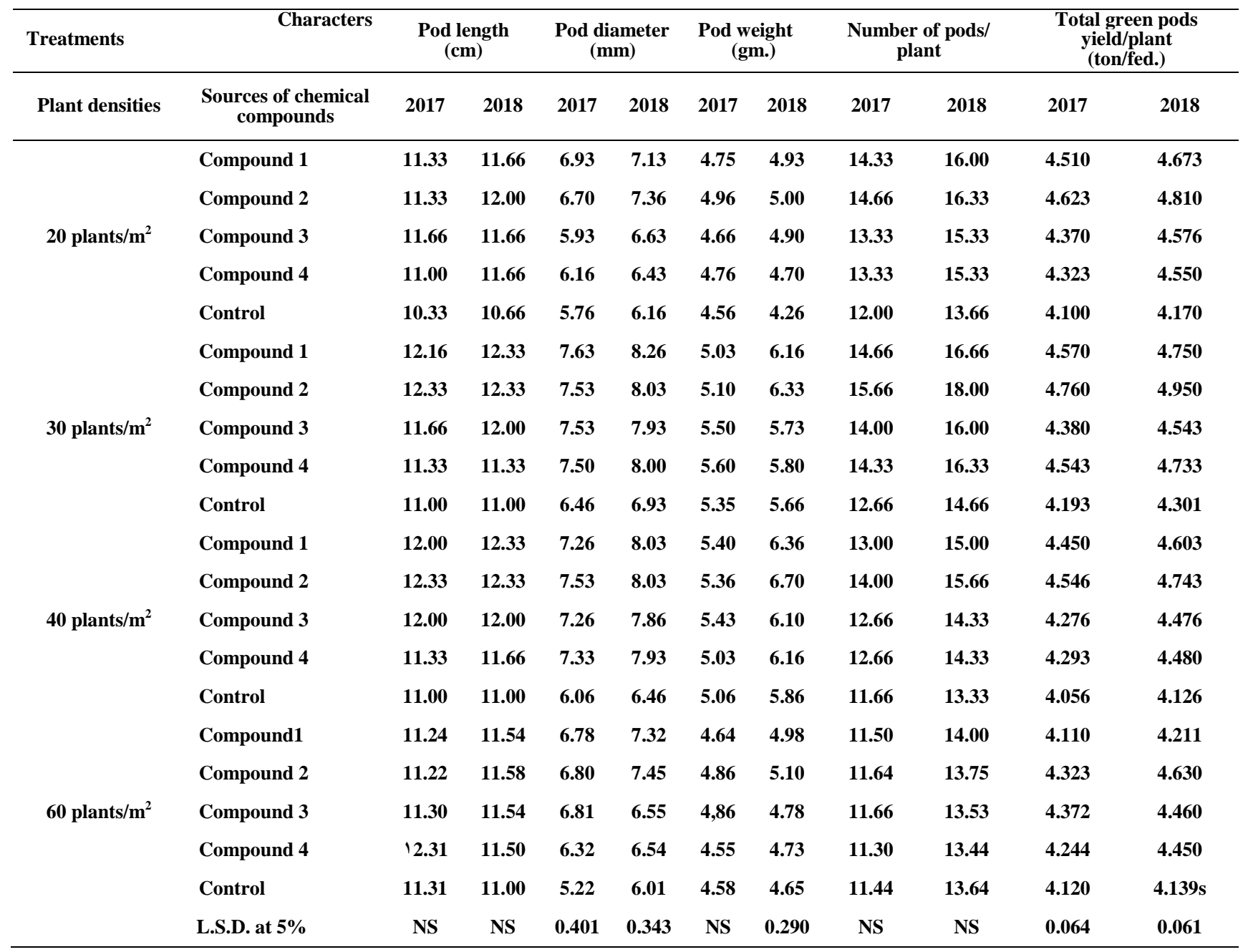

*N.S. not significant 
Table 6. Effect of plant densities and different sources of chemical compounds on chemical components of snap bean leaves during 2017 and 2018.

\begin{tabular}{|c|c|c|c|c|c|c|c|c|c|}
\hline \multirow{2}{*}{$\begin{array}{l}\text { Characters } \\
\text { Treatments }\end{array}$} & & \multicolumn{2}{|c|}{$\mathbf{N}(\%)$} & \multicolumn{2}{|c|}{$P(\%)$} & \multicolumn{2}{|c|}{$\mathbf{K}(\%)$} & \multicolumn{2}{|c|}{$\begin{array}{l}\text { Total Chlorophyll } \\
\text { (mg/g f.w.) }\end{array}$} \\
\hline & & 2017 & 2018 & 2017 & 2018 & 2017 & 2018 & 2017 & 2018 \\
\hline \multirow{7}{*}{ Plant densities } & 20 plants $/ \mathrm{m}^{2}$ & 3.24 & 3.26 & 0.41 & 0.42 & 1.19 & 1.23 & 1.89 & 1.84 \\
\hline & 30 plants $/ \mathrm{m}^{2}$ & 3.25 & 3.28 & 0.42 & 0.44 & 1.24 & 1.25 & 1.95 & 1.87 \\
\hline & 40 plants $/ \mathrm{m}^{2}$ & 3.23 & 3.24 & 0.38 & 0.39 & 1.19 & 1.21 & 1.85 & 1.79 \\
\hline & 60 plants $/ \mathrm{m}^{2}$ & 3.21 & 3.22 & 0.35 & 0.37 & 1.15 & 1.15 & 1.64 & 1.60 \\
\hline & L.S.D. at 5\% & 0.008 & 0.060 & 0.10 & 0.009 & 0.33 & 0.033 & 0.015 & 0.018 \\
\hline & Compound 1 & 3.31 & 3.32 & 0.43 & 0.45 & 1.25 & 1.26 & 1.95 & 1.87 \\
\hline & Compound 2 & 3.32 & 3.35 & 0.43 & 0.45 & 1.27 & 1.28 & 1.85 & 1.97 \\
\hline \multirow[t]{4}{*}{ Sources of chemical compounds } & Compound 3 & 3.31 & 3.32 & 0.41 & 0.42 & 1.23 & 1.25 & 1.76 & 1.83 \\
\hline & Compound 4 & 3.31 & 3.31 & 0.42 & 0.43 & 1.24 & 1.26 & 1.79 & 1.80 \\
\hline & Control & 2.98 & 2.99 & 0.34 & 0.35 & 1.03 & 1.10 & 1.57 & 1.64 \\
\hline & L.S.D. at $5 \%$ & 0.008 & 0.008 & 0.10 & 0.012 & 0.136 & 0.031 & 0.016 & 0.018 \\
\hline
\end{tabular}

differed in their leaves mineral contents, however,30 plants $/ \mathrm{m} 2$ recorded the highest amount of leaves N,P and $\mathrm{K}$ followed by 20 plants/m2 and 40 plants $/ \mathrm{m} 2$ then 60 plants $/ \mathrm{m} 2$ in both seasons, respectively. Regarding the total chlorophyll content in leaves, data showed that plant density at 30 plants $/ \mathrm{m}^{2}$ gave the highest values total chlorophyll in the two studied seasons followed by 20 plants $/ \mathrm{m}^{2}$. In this regard, EL-Atabany (2000) and Khairy (2013) found that total chlorophyll was increased with the lower plant densities.

\subsubsection{Effect of different sources of chemical compounds:}

Table (6) illustrated the effect of different sources of chemical compounds on leaves content of $\mathrm{N}, \mathrm{P}$ and $\mathrm{K}$ percentages and total chlorophyll during 2017 and 2018 seasons. The results indicated that plants treated with all studied sources of chemical compounds increased leaves content of $\mathrm{N}, \mathrm{P}$ and $\mathrm{K}$ percentages in both seasons of study compared with untreated plants.

However, the dimension order of obtained results were, chemical compound 1,compound 2, compound 3,compound 4 and control in both seasons, respectively.

Regarding total chlorophyll, data explained that all studied chemical compounds treatments had significant effect on previous parameter compared with control in both seasons.

Treating snap bean plants with chemical compound 2 recorded the highest content of leaf chemical components followed by chemical compound 1, compound 3and compound 4 in both seasons, respectively, meanwhile the control treatment recorded the lowest values.

Similar results were found by Emongor (2015) ,Dawa et al., (2014) and Nour et al., (2012).

\subsubsection{Effect of the interaction between densities and different sources of chemical compounds:}

Table (7) showed the effect of interaction between densities and different sources of chemical compounds on leaves content of $\mathrm{N}, \mathrm{P}$ and $\mathrm{K}$ percentages and total chlorophyll during 2017 and 2018 seasons. The differences between interactions treatments were significant in previous characters compared with control in both seasons.

Treatment 30 plants $/ \mathrm{m} 2$ with chemical compound 2 recorded the highest leaves content of $\mathrm{N}, \mathrm{P}, \mathrm{K}$ and total chlorophyll contents in both seasons, except $\mathrm{P}$ content in the second season, in which treated with chemical compound 1 under 30 plants/m2 came in the first place. Meanwhile the control plants under 60 plants $/ \mathrm{m} 2$ recorded the lowest values in all studied characters.

\subsection{Chemical constituents of pods:}

\subsubsection{Effect of plant densities:}

Data in Table (8) showed the effect of plant densities on chemical constituents of snap bean green pods i.e., vitamin $\mathrm{C}$, total soluble solids, acidity and fiber contents during 2017 and 2018 seasons, the data showed that all studied densities differed significantly, whereas, by increasing plant densities rising of V.C, TSS and fiber were occurred, while, decreasing of acidity was recorded in both seasons, respectively. 
Table 7. Effect of the interaction between plant densities and different sources of chemical compounds on green pod yield and its characteristic of snap bean during 2017 and 2018.

\begin{tabular}{|c|c|c|c|c|c|c|c|c|c|}
\hline \multicolumn{2}{|l|}{ Treatments } & \multicolumn{2}{|c|}{$\mathbf{N}(\%)$} & \multicolumn{2}{|c|}{$\mathbf{P}(\%)$} & \multicolumn{2}{|c|}{$\mathbf{K}(\%)$} & \multicolumn{2}{|c|}{$\begin{array}{l}\text { Total Chlorophyll } \\
\text { (mg/g f.w.) }\end{array}$} \\
\hline Plant densities & Sources of chemical compounds & 2017 & 2018 & 2017 & 2018 & 2017 & 2018 & 2017 & 2018 \\
\hline \multirow{5}{*}{20 plants $/ \mathrm{m}^{2}$} & Compound 1 & 3.30 & 3.31 & 0.39 & 0.40 & 1.23 & 1.24 & 1.94 & 1.93 \\
\hline & Compound 2 & 3.30 & 3.35 & 0.41 & 0.41 & 1.27 & 1.27 & 1.97 & 1.98 \\
\hline & Compound 3 & 3.29 & 3.32 & 0.39 & 0.39 & 1.21 & 1.24 & 1.89 & 1.86 \\
\hline & Compound 4 & 3.29 & 3.30 & 0.38 & 0.39 & 1.21 & 1.24 & 1.79 & 1.81 \\
\hline & Control & 2.97 & 2.99 & 0.30 & 0.31 & 0.99 & 1.12 & 1.58 & 1.66 \\
\hline \multirow{5}{*}{30 plants $/ \mathrm{m}^{2}$} & Compound 1 & 3.33 & 3.34 & 0.45 & 0.48 & 1.25 & 1.26 & 1.91 & 1.90 \\
\hline & Compound 2 & 3.35 & 3.37 & 0.46 & 0.47 & 1.28 & 1.29 & 1.97 & 1.98 \\
\hline & Compound 3 & 3.31 & 3.32 & 0.39 & 0.40 & 1.24 & 1.26 & 1.83 & 1.86 \\
\hline & Compound 4 & 3.32 & 3.33 & 0.44 & 0.45 & 1.25 & 1.26 & 1.83 & 1.84 \\
\hline & Control & 2.98 & 3.01 & 0.35 & 0.36 & 1.12 & 1.16 & 1.64 & 1.66 \\
\hline \multirow{4}{*}{40 plants $/ \mathrm{m}^{2}$} & Compound 1 & 3.29 & 3.30 & 0.42 & 0.44 & 1.24 & 1.24 & 1.78 & 1.80 \\
\hline & Compound 2 & 3.29 & 3.30 & 0.42 & 0.43 & 1.25 & 1.26 & 1.89 & 1.91 \\
\hline & Compound 3 & 3.29 & 3.29 & 0.41 & 0.43 & 1.23 & 1.24 & 1.75 & 1.73 \\
\hline & Compound 4 & 3.28 & 3.28 & 0.41 & 0.42 & 1.23 & 1.26 & 1.77 & 1.76 \\
\hline \multirow{7}{*}{60 plants $/ \mathrm{m}^{2}$} & Control & 2.94 & 2.96 & 0.34 & 0.34 & 0.95 & 0.99 & 1.57 & 1.60 \\
\hline & Compound 1 & 3.25 & 3.24 & 0.39 & 0.35 & 1.19 & 1.16 & 1.65 & 1.63 \\
\hline & Compound 2 & 3.26 & 3.26 & 0.38 & 0.36 & 1.20 & 1.18 & 1.63 & 1.60 \\
\hline & Compound 3 & 3.23 & 3.20 & 0.33 & 0.33 & 1.18 & 1.15 & 1.56 & 1.59 \\
\hline & Compound 4 & 3.23 & 3.21 & 0.34 & 0.33 & 1.18 & 1.16 & 1.55 & 1.54 \\
\hline & Control & 2.64 & 2.60 & 0.30 & 0.30 & 0.062 & 0.060 & 1.40 & 1.42 \\
\hline & L.S.D. at 5\% & 0.010 & 0.011 & 0.014 & 0.007 & 0.023 & 0.023 & 0.015 & 0.023 \\
\hline
\end{tabular}

*N.S. not significan

Table 8. Effect of plant densities and different sources of chemical compounds on chemical constituents of snap bean green pods during 2017 and 2018.

\begin{tabular}{|c|c|c|c|c|c|c|c|c|c|}
\hline \multirow{2}{*}{$\underbrace{\text { Characters }}_{\text {Treatments }}$} & & \multicolumn{2}{|c|}{ Vitamin C (mg/100gm f.w.) } & \multicolumn{2}{|c|}{ T.S.S (\%) } & \multicolumn{2}{|c|}{ Titratable acidity $(\%)$} & \multicolumn{2}{|c|}{$\begin{array}{c}\text { Fiber } \\
(\%)\end{array}$} \\
\hline & & 2017 & 2018 & 2017 & 2018 & 2017 & 2018 & 2017 & 2018 \\
\hline \multirow{4}{*}{ Plant densities } & 20 plants $/ \mathrm{m}^{2}$ & 8.85 & 8.68 & 4.77 & 5.48 & 0.400 & 0.359 & 5.91 & 6.21 \\
\hline & 30 plants $/ \mathrm{m}^{2}$ & 9.51 & 9.86 & 5.72 & 5.50 & 0.442 & 0.355 & 4.65 & 5.00 \\
\hline & 40 plants $/ \mathrm{m}^{2}$ & 9.99 & 10.71 & 5.97 & 5.98 & 0.371 & 0.384 & 8.21 & 6.56 \\
\hline & 60 plants $/ \mathrm{m}^{2}$ & 11.5 & 12.32 & 5.71 & 5.90 & 0.392 & 0.397 & 8.09 & 7.18 \\
\hline \multirow{7}{*}{ Sources of chemical compounds } & & 0.278 & 0.280 & 0.463 & 0.243 & 0.007 & 0.019 & 0.034 & 0.115 \\
\hline & Compound 1 & 11.01 & 11.86 & 5.85 & 5.93 & 0.388 & 0.372 & 6.01 & 5.89 \\
\hline & Compound 2 & 10.94 & 11.64 & 5.98 & 6.55 & 0.365 & 0.365 & 5.64 & 5.28 \\
\hline & Compound 3 & 10.86 & 11.20 & 5.52 & 5.61 & 0.399 & 0.384 & 5.58 & 5.25 \\
\hline & Compound 4 & 10.79 & 10.99 & 5.56 & 5.75 & 0.401 & 0.395 & 5.99 & 5.84 \\
\hline & Control & 8.92 & 9.69 & 4.90 & 5.26 & 0.474 & 0.455 & 6.84 & 6.57 \\
\hline & L.S.D. at $5 \%$ & 0.402 & 0.252 & 0.357 & 0.397 & 0.10 & 0.009 & 0.093 & 0.094 \\
\hline
\end{tabular}

\subsubsection{Effect of different sources of chemical compounds:}

The effect of different sources of chemical compounds applications on chemical constituents of snap bean green pods (pod quality), i.e., vitamin C, total soluble solids, acidity and fiber contents are presented in Table (8).

Such results revealed that all different sources of chemical compounds applications significantly increased vitamin C and total soluble solids (TSS), meanwhile decreased acidity and fiber contents compared with control in both seasons.

Pods of the plants treated with chemical compound 1 and chemical compound 2 took the first place for vitamin $\mathrm{C}$ and TSS contents, respectively and the least was pods of untreated plants. According to acidity and fiber contents ,pods of control plants recorded the highest values in both seasons compared with other treatments, whereas pods of plants treated with chemical compound 2 
and chemical compound 3recorded the lowest values in both season, respectively.

According to the effect of chemical compound 3 and chemical compound 4, the results showed nonsignificant differences with respect to vitamin $\mathrm{C}$ and TSS in both seasons.

The synergistic effect of chemical compound 1 on leaf total chlorophyll content may be attributed to its major role in increasing its endogenous concentrate on which regulate and protect photosynthetic processes ( Farago and Brunhold,1994) and in turn probably led to more synthesis of pigments including total chlorophylls and carotenoids content.

Moreover, the enhancing effect of chemical compound 1 on pod quality probably related to its major role in multifarious metabolic processes such as photosynthesis and regulating co-enzymatic reactions by which carbohydrates and proteins were metabolized ( Barakat et al., 2015).

Also, the presence of its content of cytokinins, which facilitates the mobilization of nutrients to the pods and vitamins A,B (1,2,3,6 and 7),C,D,Eand K, minerals include calcium, copper, iron, potassium, magnesium, manganes and zinc and more than 40 natural antioxidants (Makkar and Becker,1996, Mahmood et al., 2010 and Kumari et al., 2011).

The enhancement effect of chemical compound 3 and chemical compound 4 on $\mathrm{k}, \mathrm{P}, \mathrm{S}$ and $\mathrm{N}$ may be attributed to its stimulatory effects on cell division and enlargement, protein and nucleic acid synthesis and chlorophyll formation (El-Desouky et al., 1998 and Wanas, 2006).

The favorable effect of chemical compound 2 on pod quality may due to its influence on physiological and biochemical processes including photosynthesis, ion uptake, membrane permeability, enzyme activities, flowering heat protection and growth also development of plants (Arberg, 1981).

\subsubsection{Effect of the interaction between densities and different sources of chemical compounds:}

The effect of interaction between densities and different sources of chemical compounds applications on vitamin C, total soluble solids (TSS), acidity and fiber contents of snap bean green pods were shown in Table (9).

It is obvious that the interaction treatments recorded significant differences compared with control in all studied parameters, except TSS in both seasons and acidity in the first season.

Regarding vitamin C and TSS contents in pods, planting at 30 plants $/ \mathrm{m}^{2}$ under treated with chemical compound 1 and chemical compound 2 recorded the highest values, in both seasons, respectively, while untreated plants which planting at 20 plants $/ \mathrm{m}^{2}$ recorded the lowest values. Moreover, acidity and fiber contents of pods were highly in planting at 20 plants $/ \mathrm{m} 2$ untreated plants; whereas 30 plants $/ \mathrm{m}^{2}$ treated with chemical compound 2 recorded the lowest values in both seasons.

Table 9. Interaction between plant densities and different sources of chemical compounds on chemical constituents of snap bean green pods during 2017 and 2018.

\begin{tabular}{|c|c|c|c|c|c|c|c|c|c|}
\hline \multicolumn{2}{|c|}{$\begin{array}{c}\text { Characters } \\
\text { Treatments } \\
\end{array}$} & \multicolumn{2}{|c|}{ Vitamin C (mg/100gm f.w.) } & \multicolumn{2}{|c|}{ T.S.S (\%) } & \multicolumn{2}{|c|}{ Titratable acidity $(\%)$} & \multicolumn{2}{|c|}{$\begin{array}{c}\text { Fiber } \\
(\%)\end{array}$} \\
\hline Plant densities & Sources of chemical compounds & 2017 & 2018 & 2017 & 2018 & 2017 & 2018 & 2017 & 2018 \\
\hline \multirow{5}{*}{20 plants $/ \mathrm{m}^{2}$} & Compound 1 & 10.84 & 11.44 & 6.07 & 6.43 & 0.422 & 0.384 & 7.12 & 6.76 \\
\hline & Compound 2 & 11.01 & 11.24 & 6.43 & 6.72 & 0.378 & 0.372 & 6.42 & 6.28 \\
\hline & Compound 3 & 10.98 & 11.01 & 6.01 & 6.34 & 0.423 & 0.381 & 6.47 & 6.27 \\
\hline & Compound 4 & 9.37 & 10.98 & 6.00 & 6.42 & 0.435 & 0.419 & 6.75 & 6.54 \\
\hline & Control & 8.15 & 8.62 & 5.02 & 5.78 & 0.513 & 0.493 & 8.22 & 7.82 \\
\hline \multirow{6}{*}{30 plants $/ \mathbf{m}^{2}$} & Compound 1 & 11.65 & 12.27 & 7.00 & 7.71 & 0.349 & 0.331 & 5.78 & 5.66 \\
\hline & Compound 2 & 11.32 & 12.05 & 7.43 & 7.25 & 0.339 & 0.322 & 5.36 & 5.32 \\
\hline & Compound 3 & 11.21 & 11.64 & 6.67 & 6.56 & 0.462 & 0.361 & 4.88 & 4.93 \\
\hline & Compound 4 & 11.17 & 11.21 & 6.75 & 6.74 & 0.372 & 0.367 & 5.66 & 5.61 \\
\hline & Control & 8.65 & 9.02 & 6.15 & 6.44 & 0.424 & 0.411 & 6.41 & 6.15 \\
\hline & Compound 1 & 12.33 & 13.47 & 6.94 & 7.20 & 0.368 & 0.349 & 8.32 & 7.88 \\
\hline \multirow{3}{*}{40 plants $/ \mathrm{m}^{2}$} & Compound 2 & 12.17 & 13.04 & 7.12 & 7.34 & 0.349 & 0.346 & 7.76 & 7.18 \\
\hline & Compound 3 & 11.93 & 12.47 & 6.21 & 6.43 & 0.359 & 0.352 & 7.93 & 7.21 \\
\hline & Compound 4 & 11.84 & 12.07 & 6.10 & 6.78 & 0.392 & 0.371 & 8.22 & 7.86 \\
\hline \multirow{7}{*}{60 plants $/ \mathrm{m}^{2}$} & Control & 9.47 & 10.12 & 5.00 & 6.25 & 0.438 & 0.427 & 8.69 & 8.12 \\
\hline & Compound 1 & 9.65 & 10.34 & 6.03 & 6.00 & 0.443 & 0.377 & 7.22 & 6.55 \\
\hline & Compound 2 & 10.00 & 10.21 & 6.33 & 6.21 & 0.345 & 0.376 & 6.44 & 6.37 \\
\hline & Compound 3 & 9.54 & 10.21 & 6.04 & 6.01 & 0.443 & 0.395 & 6.35 & 6.34 \\
\hline & Compound 4 & 8.45 & 9.54 & 6.22 & 6.31 & 0.440 & 0.422 & 6.75 & 6.56 \\
\hline & Control & 7.00 & 7.53 & 5.01 & 5.85 & 0.531 & 0.488 & 8.12 & 7.99 \\
\hline & L.S.D. at $5 \%$ & 0.461 & 0.423 & NS & NS & NS & 0.024 & 0.137 & 0.134 \\
\hline
\end{tabular}

*N.S. not significant 


\section{Doaa, M. Mostafa et al., 2019}

\section{CONCLUSION}

It could be concluded that under clay soil condition and furrow irrigation treating snap bean cv.Polista with some chemical compounds consist of some stimulatory substances in purpose to face the unstable weather and weather fluctuations specially low temperature with fall season, i.e., chemical compound 2 (2L/fed.) with planting 30 plants $/ \mathrm{m}^{2}$, which could be achieves significant values in improving green pods yield without remarkable changes in yield quality.

However, it can be noticed that the four studied densities could be responded to all used chemical compounds treatments, though 30 plants $/ \mathrm{m}^{2}$ surpassed 40 plants $/ \mathrm{m}^{2}$ also20 and 60 plants $/ \mathrm{m}^{2}$ and take place in diminution order, as follow: compound 2, compound 1 , compound 3 and compound 4 for increasing yield and quality under local environmental conditions of this experiment.

\section{REFERENCES}

AOAC (1975). Association Agricultural chemist, Washington, D. C., 200 Official Method of Analysis 12th ed. 44: $94-117$.

Amer AH, EL-Gizy SM, EL-Ghareeb IM, ELSharkawy MS (2001). Response of pea (Pisium sativum L.) plants to plant density and foliar nutrient. J. Agric. Sci. Mansoura Univ., 26(5):29832996.

Arberg B (1981). Plant growth regulators mono substituted benzoic acid. Swed. Agric. Res., 1: 93105.

Barnett JA, Payne RW, Yarrow D (1990). Yeast, characteristies and identification. Cambridge Univeresity Press, London, PP: 999.

Basra SMA, Iftikher MN, Afzal I (2011). Potential of moringa ( Moringa oleifera) leaf extract as priming agent for hybrid maize seeds .Int. J. Agric. Biol., 13:1006-1010.

Bodanns RS, Chan PC (1979). Auxins as a scavenger of singlet oxygen. FBES Lett.,105:195196.

Bowler C, Montogh MV, Inze D, (1992). Superoxide dismutase and stress tolerance.Ann. Rev,Plant Physiol. Plant Mol. Biol., 48: 223-250.

Buis R, Barthou H, Roux B, (1988). Effect of temporary chilling on foliar and culinary growth and productivity in soybean (Glycine max). Annals of Botany, 61: 705-715.

Chapman HD, and Pratt PF, (1961). Methods of Analysis for Soils, Plants and Waters.University of California, Division of Agricultural Sciences, California.

Chojnacka K, Saeid A, Witkowska Z, Tuhy L (2012). Biologically active compounds in seaweed extracts - the prospects for the application. The
Open Conference Proceedings Journal. 3(1):20-28. doi:10.2174/1876326x01203020020.

Dale JE (1964). Some effect of alterating temperature on the growth French bean plants. Ann.Bot., 8:127-135.

Dawa KK, Farid SM, EL-Bauomy AE (2014). Effect of bio fertilizers inoculation methods and some foliar application treatments on yield and quality of pea plants. J Plant Production Mansoura Univ., 5(11): 1957-1975.

Darwesh FMA (2012). Cowpea (Vigina unguiculata L) productivity as affected by combination effect between sowing dates and plant population. J. Plant Production, Mansoura Univ., 3 (11): 2711-2722.

El-Desouky SA, Wanas AL, Khedr ZM (1998). Utilization of some natural plant extracts of garlic and yeast as seed-soaked materials to squash ( Cucurbita pepo L). 1- Effect on growth , sex expression and fruit yield and quality .J Agric. Sci. Moshtohorm Zagazig Univ., 35(2):839-854.

EL-Atabany AMMS (2000). Physiological Studies on Pea Plants. M.Sc. Thesis, Fac. Agric. Zagazig Univ.124p.

EL-Tohamy WA, EL-Greadly NHM (2007). Physiological responses, growth, yield and quality of snap beans in response to foliar application of yeast, vitamin $\mathrm{E}$ and zinc under sandy soil conditions. Aust. J. Basic \& Appl. Sci., 1(3): 294-299.

EL-Tohamy WA, Schnitzler WH, EL-Behairy UA, Singer SM (1999). Effect of long-term drought stress on growth and yield of bean plants (Phaseolus vulgaris L. ) Journal of applied Botany-Angewandte Botanik., 73:173-177.

Emongor VE ( 2015). Effect of moringa leaf extract on growth, yield and yield components of snap bean ( Phaseolus vulgaris ). JAST, 6(2):114122.

Farago S, Brunhold C (1994). Regulations of thiol contents in maize roots by intermediates and effect of glutathione synthesis. J. plant Physoil., 144:433437.

Fatahallah MA (1992). Response of tomato to various irrigation regimes in relationtofarmyard manures fertilization.Plant growth and some chemical constants.Menofiya. J. Agric. Res., 17:1263-1283.

Fryer MJ, Oxborouph K, Martin B, Ort DR, Baker NR (1995). Factor associated with depression of photosynthetic, quantum efficiency in maiz at low growth temperature. Plant Physiology., 108:761767.

Greaves JA (1996). Improving suboptimal temperature tolerance in maiz- the scarch for variation Journal of Experimental Botany., 47:307323. 
Harborne JB (1980). Plant phenolics. Insecondary plant products. E.A.Bell. B.V. Charlwood., PP:329402. Berln:Springer Veriag. 674.

Hussain M, Farooq M, Shahzad MA, Basra SMA, lee D (2013). Application of moringa alleopathy in crops sciences. In: Cheema et al., (ed). Allelopathy. Springer Berlin Heidelberg., pp:57-58.

Kazemi E, Naseri R, Karimi Z, Emami T (2012). Variability of grain yield and yield components of white bean (Phaseolus vulgaris L. ) cultivars as affected by different plant density in Western Iran. American-Eurasian J. Agric.\& Environ. Sci., 12 (1):17-22.

Khairy EAF(2013). Effect of plant population and sowing dates on growth and yield of dry bean ( Phaseolus vulgaris L.). Ph.D. Thesis. Fac. Agric. Suez Canal. Univ. 93p.

Klessige DF, Malamy J (1994). The salicylic acid signal in plant . Plant Mol.Biol., 26:1439.

Kothule VG, Bhalerao RK, Sathe BV (2003). Effect of exogenous application of growth regulators on growth, biomass partitioning and yield in soybean. Annals of Plant Physiology., 17(1):95-99.

Kumari R, Kaur I, Bhatnagar AK (2011). Effect of aqueous extract of Sargassum johnstonii setchell and gardener on growth, yield and quality of Lycopersicon esculentum Mill. J. App. Phycol., 23:623-633.

Lichtenthaler HK, Wellburn AR (1983). Determinations of total carotenoids and chlorophylls $\mathrm{a}$ and $\mathrm{b}$ of leaf extracts in different solvents. Biochem. Soc. Trans., 11(5):591-592.

Mahmoodm KT, Mugal T, Haq IU (2010). A natural gift: A review. J. Pharm. Sci. Res., 2:775781.

Mattagajasingh SN, Kar M (1989). Changes in the antioxidant system during the greening of etiolated wheat leaves. J. Plant Physiol., 134: 656-660.

Maynard AJ (1970). Methods in food analysis. Academic Press New York, London, 176pp.

Moot, DJ, McNeil DL (1995). Yield components, harvest index and plant type in relation to yield differences in field pea genotypes. Euphytica., 86: 31-40.

Nour KAM, Mansour NTS, Eisa GSA (2012). Effect of some antioxidants on some physiological and anatomical characters of snap bean plants under sandy soil conditions.New York Science Journal., 5(5):1-9.

Novabour S, Morris $\mathrm{K}$, Allen R, Harrison E, Wollaston $V$ (2003). Expression of senescence enhanced genes in response to oxidative stress. Journal of Experimental Botany., 54:2285-2292.

Raskin I (1992). Anew plant hormone. Plant Physiol., 99:799-803.

Romheld V, Marsechner H (1991). Function of micronutrients in plant. In Micro-Nutrients in agriculture, 2 nd Ed Motivedm J.J. Cox. F. R., Shuman, L. M. and Welch, R. M. Eds. Soil Science Society of American Madison, W., PP.297-328.

Singer Sm, EL-Tohamy WA, Abo-Hadid AF, Markhartm, AH, Li PH (1996). Chilling and water stress injury in bean (Phaseolus vulgaris L ) is reduced by pretreatment with $\mathrm{CaCl}$,mefluidide, KCl. Egypt. J Hort., 23:77-87.

Umebese CE, Olatimilehin TO, Ogunsusi TA (2009). Salicylic acid protects nitrate reductase activity, growth and proline in amaranth and tomato plants during water deficit. Amer. J. Agri. Biolo. Sci., 4(3): 224-229.

Wanas AL (2006). Trials for improving growth and productivity of tomato plants grown in winter .Annals Agric. Sci. Moshtohor., 44(3):466-471.

Wentworth M, Murchie EH, Gray JE, Villege D,

Pastenes C, Pinto M, Horton $P$ (2006). Differential adaptation of two varieties of common bean to abiotic stress II. Acclimation of Photosynthesis .Journal of Experimental Botany., 57(3): 699-709.

Wilkins MB (1984). Advanced plant physiology. Longman, London.

Yousri SS (1990). Effects of planting date and phosphorus fertilization on growth, yield and quality of peas (Pisum sativum.L.). M.Sc. Thesis. Faculty of Agric. Alexandria. Univ. 
Doaa, M. Mostafa et al., 2019

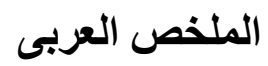

استجابة نباتات الفاصوليا الخضر اء لبعض الكثافات النباتية والمركبات الكيميائية المختلفة تحت الظروف المباردة المناخية الباردة الباتهة

\section{دعاء محمد مصطفي احمد ، عبير ابراهيم شبانة ، محمد محمد رمضان}

اقسام بحوث الخضر - معهد بحوث البساتين - مركز البحوث الزر اعية

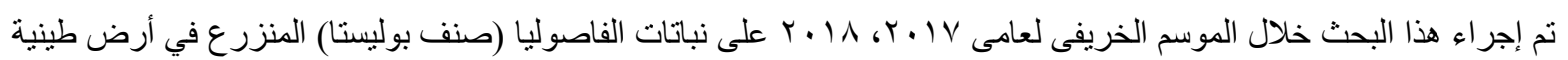

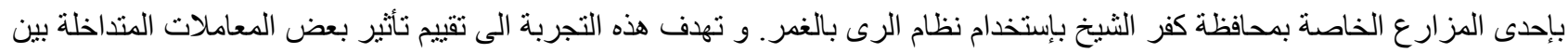

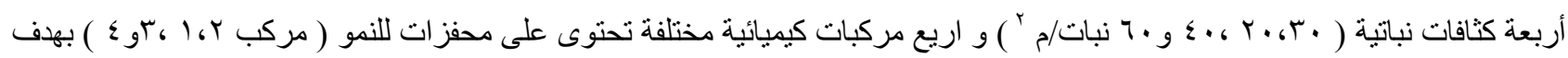

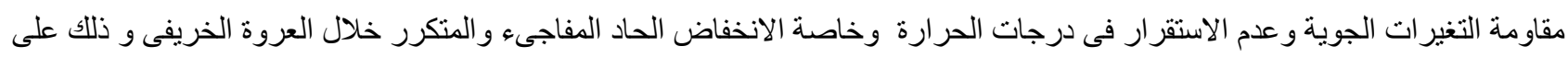

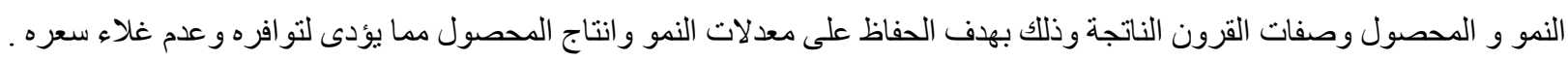
وكانت النتائج كالتالى: كانت جميع الكثافات النباتية المستخدمة خاصة مع توليفات من المركبات الكيميائية ذات تاثثير ايجابى مقارنة بمعاملة الكنترول ، حيث سجلت

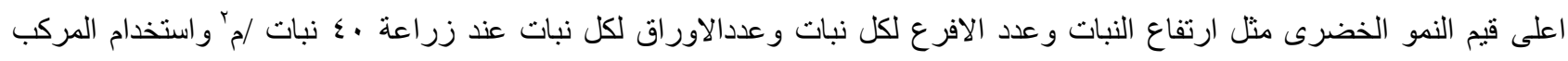

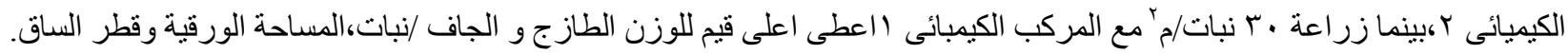
و فيما يخص تاثير التداخل على وزن القرون فى موسم النمو الاول فقطو، وطول القرن و عدد القرون /نبات في كلا الموسمين لم تظهر النتائج

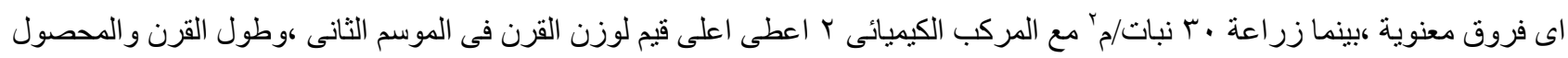

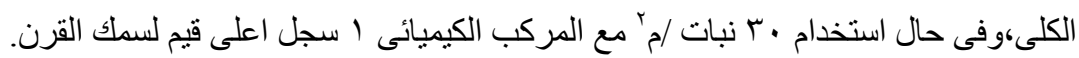

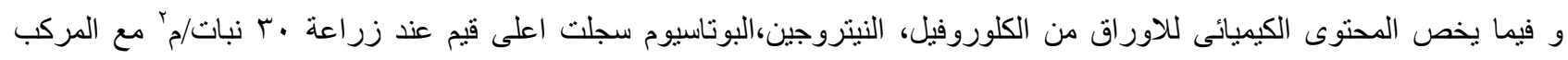

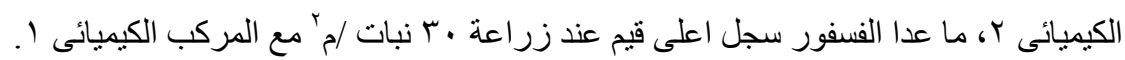

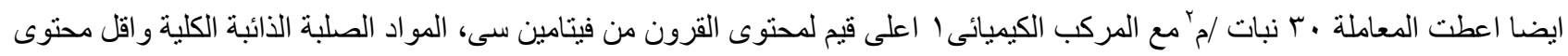
من الالياف و الحموضة وبالتالى الحصول على اعلى جودة للقرون. 